\title{
SURVEI E-COMMERCE 2020: PELUANG DAN TANTANGAN SURVEI PRIORITAS NASIONAL DI MASA PANDEMI COVID-19
}

\author{
(The 2020 E-commerce Survey: Opportunities and Challenges of A National Priority Survey \\ During the Covid-19 Pandemic)
}

\author{
Rima Untari ${ }^{1}$, Andri Yudhi Supriadi ${ }^{2}$, Aris Rusyiana ${ }^{3}$ \\ Subdit Statistik Komunikasi dan Teknologi Informasi, Badan Pusat Statistik ${ }^{1,2}$ \\ Biro Bina Program, Badan Pusat Statistik ${ }^{3}$ \\ Jl. Dr. Sutomo No.6-8, Jakarta 10710 \\ E-mail: rimauntari@bps.go.id
}

\begin{abstract}
ABSTRAK
Badan Pusat Statistik (BPS) merupakan salah satu kementerian/lembaga yang mengalami pengurangan pagu anggaran (refocussing budget) akibat pandemi Covid-19. Refocussing anggaran ini juga berdampak terhadap pelaksanaan sensus dan survei BPS, salah satunya Survei $E$-commerce 2020. Survei $E$ commerce 2020 termasuk salah satu survei yang harus dilaksanakan dan beradaptasi di masa pandemi Covid-19 karena termasuk bagian dari Program Prioritas Nasional dalam Rencana Kerja Pemerintah (RKP) 2020. Penelitian ini menggunakan metode analisis SWOT melalui telaah dokumen resmi Survei E-commerce dan dokumen-dokumen lain yang relevan secara sistematis (systematic literature review) terkait Survei $E$ commerce 2019 dan Survei E-commerce 2020. Analisis SWOT digunakan untuk mengevaluasi pelaksanaan Survei E-commerce tahun 2019 dan 2020 menurut perspektif internal dan eksternal untuk strength (kekuatan), weakness (kelemahan), opportunities (peluang), dan threats (tantangan). Secara umum, penelitian kualitatif ini bertujuan untuk memberikan gambaran secara deskriptif mengenai 3 (tiga) hal, yaitu: (1) Urgensi Survei E-commerce, (2) Persamaan dan perbedaan tata laksana survei E-commerce antara sebelum dan di masa pandemi Covid-19; dan (3) Peluang dan tantangan Survei E-commerce di masa pandemi Covid-19. Survei E-commerce 2020 telah menunjukkan beberapa kontribusi penting dalam mendukung Program Prioritas Nasional sehingga tetap dilakukan di masa pandemi Covid-19 dengan berbagai penyesuaian pada tata laksana survei. Dengan memperhatikan sudut pandang internal dan eksternal, Survei E-commerce 2020 mempunyai peluang dan tantangan yang dapat dijadikan pembelajaran apabila suatu saat terjadi force majeur yang membuat BPS harus mempertimbangkan penyesuaian pada metodologi serta keseluruhan tata laksana kegiatan statistik.
\end{abstract}

Kata kunci: Analisis SWOT, Program Prioritas Nasional, Refocusing Anggaran, Survei E-commerce

\section{ABSTRACT}

BPS-Statistics Indonesia is one of the ministries/institutions that has experienced a refocusing budget due to the Covid-19 pandemic. The budget refocusing also has an impact on the implementation of the BPS census and survey, one of which is the 2020 E-commerce Survey. The 2020 E-commerce Survey is one of the surveys that must be carried out and adapted during the Covid-19 pandemic because it is part of the National Priority Program in Government Work Plan (RKP) 2020. The research uses the SWOT analysis method through systematic review of official E-commerce survey documents and other relevant documents (systematic literature review) related to the 2019 E-commerce Survey and 2020 E-commerce Survey. SWOT analysis used to carry out the 2019 and 2020 E-commerce survey according to internal and external perspectives for strengths, weaknesses, opportunities, and threats. In general, this qualitative research aims to provide a descriptive description of 3 (three) things, namely: (1) The Urgency of the E-commerce Survey, (2) Similarities and differences in the E-commerce survey administration between before and during the Covid-19 pandemic; and (3) Opportunities and threats for the E-commerce Survey during the Covid-19 pandemic. The 2020 E-commerce Survey has shown several important contributions in supporting the National Priority Program so that it will continue to be carried out during the Covid-19 pandemic with various adjustments to the management survey. By paying attention to internal and external perspectives, the 2020 E-commerce Survey has opportunities and threats that can be used as lessons if one day a force majeur occurs which makes BPS-Statistics Indonesia have to review the methodology and overall management of statistical activities.

Keywords: SWOT analysis, National Priority Program, Budget Refocusing, E-commerce Survey 


\section{PENDAHULUAN}

Sejak pertama kali mengumumkan kasus positif Covid-19 pada awal bulan Maret 2020, Indonesia termasuk ke dalam 215 negara/teritorial dan International Conveyances (menurut skema geografis PBB) yang terkena dampak pademi Covid-19. Menurut situs website Worldometer (4 Agustus 2020), dengan jumlah total kasus terkonfirmasi positif (113.134 kasus), Indonesia menempati urutan ke-23 dari 213 negara/teritorial dan 2 (dua) International Conveyances (Kapal Pesiar Diamond Princess dan ZM Zaandam) dengan total kasus positif Covid-19 dan total kematian akibat Covid-19 terbanyak. Di antara negara-negara Asia, Indonesia menempati urutan ke-10 negara terbanyak kasus Covid-19, dan peringkat teratas kasus terbanyak meninggal akibat Covid19 (5.302 kasus) di antara negara-negara di kawasan Asia Tenggara.

Meskipun data yang bisa diakses di website "kawalcovid19.id" per tanggal 4 Agustus 2020 menunjukkan kabar menggembirakan bahwa sebanyak 70.237 pasien dikabarkan sembuh akan tetapi masih terdapat 37.595 pasien dalam perawatan di tengah ancaman angka kematian akibat Covid-19 (4,69\%). Angka statistik pandemi ini mengkhawatirkan karena menunjukkan tingkat kematian akibat Covid-19 per total kasus positif terkonfirmasi di Indonesia di atas tingkat kematian dunia (3,78\%). Sebagian yang meninggal adalah tenaga medis, baik dokter maupun perawat. Menurut Ikatan Dokter Indonesia (IDI) (2020) terdapat 72 orang dokter meninggal dan terkonfirmasi positif Covid-19 sampai dengan awal Agustus 2020. Selain itu, Pengurus Besar Persatuan Perawat Nasional Indonesia (PPNI) menyebutkan sebanyak 51 perawat meninggal dunia sampai akhir Juli 2020.

Pandemi Covid-19 yang disebabkan oleh virus SARS-CoV-2 telah berlangsung selama 6 (enam) bulan di Indonesia, sejak penetapan status tanggap darurat bencana diumumkan pada awal Maret 2020. Pandemi tersebut juga telah menimbulkan dampak luar biasa bagi segenap aspek kehidupan meliputi sosial, ekonomi, kesehatan masyarakat, politik dan keamanan. Situasi tersebut memaksa pemerintah dan masyarakat untuk beradaptasi dengan situasi dan kebiasaan baru. Berbagai upaya telah dilakukan pemerintah, diantaranya kebijakan Pembatasan Sosial Berskala Besar (PSBB), penerapan dan sosialisasi protokol kesehatan untuk meminimalisasi penularan penyakit, pembatasan mobilitas dan kerumunan masyarakat yang telah mengubah seketika pola belajar dan pola kerja dari tatap muka (offline) menjadi daring (online), dan peningkatan remote work untuk pekerja sektor publik dan swasta. APBN dan APBD dialihkan (refocussing) untuk pencegahan penularan Covid-19 (Instruksi Presiden Nomor 4 Tahun 2020) sebesar 695 Triliun Rupiah, dalam bentuk belanja penanganan kesehatan, penanganan dampak ekonomi, dan penyediaan jaring pengaman sosial. Alokasi anggaran penanganan kesehatan digunakan untuk penyediaan Alat Perlindungan Diri (APD), serta pendirian pusat karantina dan laboratorium pengujian tes rapid/swab. Sementara, penyediaan jaring pengaman sosial dialokasikan untuk subsidi bantuan langsung tunai kepada masyarakat, dan lain-lain. Pemerintah seperti berpacu dengan waktu untuk memulihkan keselamatan jiwa masyarakat dari bencana pandemi Covid-19 dan di sisi lain menyelamatkan roda perekonomian, seperti yang disampaikan dalam Instruksi Presiden Nomor 4 Tahun 2020. Selain itu, pemerintah juga mengalokasikan anggaran untuk penanganan dampak ekonomi.

Sebagai salah satu kementrian/lembaga (K/L), Badan Pusat Statistik (BPS) mengalami pengurangan pagu anggaran (refocussing budget) melalui Surat Sekretaris Utama BPS RI Nomor B-209/BPS/2120/04/2020 tanggal 22 April 2020. Kebijakan ini berimplikasi pada pengurangan sebesar 45,46\% dari total pagu BPS Pusat/Daerah, yaitu dari 7,92 Triliun Rupiah menjadi 4,64 Triliun Rupiah. Refocussing anggaran ini juga berimbas banyak terhadap pelaksanaan sensus dan survei BPS, antara lain Sensus Penduduk 2020, Kerangka Sampel Area (KSA), Survei Angkatan Kerja Nasional (Sakernas), Survei E-commerce, dan survei-survei lain.

Survei E-commerce 2020 merupakan survei tahunan yang dilakukan sejak tahun 2019, bertujuan untuk menyediakan data distribusi pelaku usaha e-commerce di Indonesia, menyediakan indikator pokok yang terkait e-commerce seperti jumlah usaha, volume transaksi, dan nilai transaksi, serta mendukung penyusunan Produk Domestik Bruto (PDB) (BPS, 2020). Survei Ecommerce 2020 termasuk salah satu survei yang harus dilaksanakan dan beradaptasi di masa pandemi Covid-19 karena termasuk bagian dari Program Prioritas Nasional dalam Rencana Kerja Pemerintah (RKP) 2020. PSBB yang diterapkan selama pandemi Covid-19 telah mengubah pola $e$ - 
commerce di Indonesia yang diindikasikan oleh kenaikan tren penjualan barang/jasa dan pergeseran kategori yang mengalami kenaikan atau penurunan penjualan barang/jasa pada $e-$ commerce (BPS, 2020). Seperti apa Survei E-commerce 2020 beradaptasi di masa pandemi Covid19 , menjadi salah satu pembahasan utama dalam makalah ini.

Beberapa pustaka yang ada mendefinisikan e-commerce dengan pengertian yang beragam (McLeod, 2007; Shelly, et.al, 2007; dan Laudon dan Laudon, 1998; dan OECD, 2011). McLeod (2007) menekankan pengertian e-commerce pada penggunaan jaringan komunikasi dan komputer untuk melaksanakan proses transaksi jual/beli barang dan jasa. Sedangkan, menurut Shelly, dkk (2007), e-commerce merupakan transaksi bisnis yang terjadi dalam jaringan elektronik seperti internet. Adapun, di tahun 1998, Laudon, K.C dan Laudon, J.P di dalam buku yang berjudul "Management Information System, New Approaches to Organization and Technology" menyebutkan e-commerce adalah suatu proses membeli dan menjual produk-produk secara elektronik oleh konsumen dan dari perusahaan ke perusahaan dengan komputer sebagai perantara transaksi. Organisation of Economic Co-operation and Development (OECD) mendefinisikan e-commerce sebagai penjualan atau pembelian barang/jasa yang terjadi melalui jaringan komputer atau internet, dengan metode spesifik yang didesain khusus untuk menerima atau melakukan pesanan. Barang/jasa dipesan melalui metode tersebut, meskipun pembayaran dan pengiriman barang/jasanya tidak harus via online. Definisi e-commerce yang digunakan pada Survei $E$-commerce yaitu penjualan barang/jasa yang terjadi melalui jaringan komputer atau internet, dengan metode spesifik yang didesain khusus untuk menerima pesanan dimana barang/jasa dipesan melalui metode tersebut, meskipun pembayaran dan pengiriman barang/jasanya tidak harus via online (BPS, 2020).

Sevelius et.al (2020) dalam penelitiannya berjudul "Research with Marginalized Communities: Challenges to Continuity During the COVID-19 Pandemic" menjelaskan tentang tantangan dan manajemen keberlanjutan survei selama masa pandemi Covid-19. Dengan mempertimbangkan kelangkaan pustaka yang menerangkan bagaimana persamaan dan perbedaan tata laksana survei yang dilakukan selama pandemi Covid-19 (Sevelius et.al, 2020), kami melakukan tinjauan deskriptif menggunakan analisis SWOT untuk mengevaluasi pelaksanaan Survei E-commerce 2019 dan Survei E-commerce 2020. Secara umum, penelitian kualitatif ini bertujuan untuk memberikan gambaran secara deskriptif mengenai 3 (tiga) hal, yaitu: (1) Urgensi Survei E-commerce, (2) Persamaan dan perbedaan tata laksana survei $E$-commerce antara sebelum dan di masa pandemi Covid-19; dan (3) Peluang dan tantangan Survei E-commerce di masa pandemi Covid-19.

\section{METODE}

Penelitian ini menggunakan metode Analisis SWOT melalui telaah dokumen resmi Survei $E$ commerce dan dokumen-dokumen lain yang relevan secara sistematis (systematic literature review) terkait kedua Survei E-commerce, yaitu Survei E-commerce 2019 dan Survei E-commerce 2020. Analisis SWOT digunakan untuk mengevaluasi pelaksanaan Survei E-commerce tahun 2019 dan 2020 menurut perspektif internal dan eksternal untuk strength (kekuatan), weakness (kelemahan), opportunities (peluang), dan threats (tantangan). Metode tersebut digunakan dalam makalah ini karena relevan untuk mengevaluasi perbandingan tata laksana Survei E-commerce sebelum dan di masa pandemi Covid-19.

Analisis SWOT merujuk pada penilaian (assessment) dan evaluasi komprehensif, sistematis, dan akurat untuk semua variasi kekuatan (strenght), kelemahan (weakness), peluang (opportunities), dan tantangan (threats) dalam suatu kegiatan (Gurel and Tat, 2017; Leigh, 2010). Gurel and Tat (2017) menerangkan bahwa analisis SWOT merupakan suatu teknik analisis yang mempunyai perspektif luas serta menawarkan solusi dalam perspektif luas dan terkini. Analisis SWOT juga menyajikan peluang kepada suatu organisasi untuk menyajikan secara sekaligus nilainilai positif dan negatif. Penyajian ini dapat membantu manajemen organisasi untuk mengambil peluang-peluang yang menguntungkan. Di sisi lain, dengan memahami kelemahan dan tantangan, memungkinkan manajemen organisasi untuk meminimalisasi kerugian dan mengelola resiko. Gurel dan Tat (2017) juga menjelaskan bahwa analisis SWOT mampu menyajikan kelebihan, kelemahan, peluang, dan tantangan serta mampu menjadi alat analisis di setiap jenjang analisis dan dapat digunakan dalam lingkup organisasi yang lebih luas, baik di sektor publik maupun swasta. Leigh 
(2010) menerangkan bahwa analisis SWOT merupakan serangkaian proses identifikasi, evaluasi, dan kontrol faktor-faktor internal dan eksternal menyangkut kinerja organisasi yang dilakukan oleh pihak manajemen dalam menentukan langkah-langkah perencanaan strategis organisasi untuk meningkatan kinerja. Namun, pada umunya organisasi hanya mengambil tahap identifikasi dari 3 (tiga) tahapan yaitu identifikasi, evaluasi , dan kontrol. Pada umumnya, para pemangku kebijakan membuat suatu matriks $2 \times 2$ untuk menunjukkan peningkatan kinerja internal (internal performances enhancers) sebagai kekuatan dan penghambat internal (internal inhebitors) sebagai kelemahan. Di sisi lain, peningkatan kinerja eksternal diklasifikasikan sebagai peluang dan penghambat eksternal sebagai tantangan.

\section{HASIL DAN PEMBAHASAN}

Tabel 1 menyajikan secara ringkas tata laksana Survei E-commerce 2019 dan Survei Ecommerce 2020 berdasarkan aspek cakupan, jumlah petugas, jumlah sampel, response rate, metodologi, instrumen, dan anggaran. Perbedaan yang paling mencolok antara Survei $E$ commerce 2019 dan Survei E-commerce 2020 terletak pada metodologinya.

Tabel 1. Perbandingan Tata Laksana Survei E-commerce 2019 dan Survei E-commerce 2020.

\begin{tabular}{|c|c|c|c|}
\hline No. & Keterangan & Survei E-commerce 2019 & Survei E-commerce 2020 \\
\hline 1 & Prioritas Nasional & $\begin{array}{l}\text { Rencana Kerja Pemerintah (RKP) } 2019 \\
\text { Mendukung Program Prioritas Nasional } \\
\text { Ketiga }\end{array}$ & $\begin{array}{l}\text { Rencana Kerja Pemerintah (RKP) } 2020 \\
\text { Mendukung Program Prioritas Nasional } \\
\text { Pertama }\end{array}$ \\
\hline 2 & Cakupan & $\begin{array}{l}\text { (1) } 34 \text { Provinsi; } 101 \mathrm{Kab} / \text { Kota } \\
\text { (2) Kategori Usaha KBLI selain O dan T }\end{array}$ & $\begin{array}{l}\text { (1) } 34 \text { Provinsi; } 101 \mathrm{Kab} / \text { Kota } \\
\text { (2) Kategori Usaha KBLI selain O, T, \& U }\end{array}$ \\
\hline 3 & Jumlah Petugas & $\begin{array}{l}\text { (1) Instruktur Nasional (Innas): } 64 \\
\text { (2) Petugas: } 1.571\end{array}$ & $\begin{array}{l}\text { (1) Instruktur Nasional (Innas): } 62 \\
\text { (2) Petugas: } 1.620\end{array}$ \\
\hline 4 & Jumlah Sampel & $\begin{array}{l}\text { 3.504 Blok Sensus } \\
\text { (18.516 usaha/perusahaan) }\end{array}$ & 17.063 usaha/perusahaan \\
\hline 5 & Response Rate & $\begin{array}{l}\text { (1) Target: } 80,5 \% \\
\text { (2) Realisasi: } 100 \%\end{array}$ & $\begin{array}{l}\text { (1) Target: } 70 \% \\
\text { (2) Realisasi: } 99,71 \%\end{array}$ \\
\hline 6 & Metodologi & $\begin{array}{l}\text { (1) Memilih Blok Sensus secara } \\
\text { sistematik (Systematic Sampling) } \\
\text { (2) Listing Blok Sensus terpilih } \\
\text { (3) Wawancara Langsung (door to } \\
\text { door) }\end{array}$ & $\begin{array}{l}\text { (1) Pencacahan Lengkap (take all) } \\
\text { usaha e-commerce dari hasil listing } \\
\text { Survei E-commerce } 2019 \text { dan hasil Big } \\
\text { Data Crawling Marketplace dari Tim } \\
\text { Polstat STIS yang dilengkapi informasi } \\
\text { nomor telepon/ handphone } \\
\text { (2) Metode kombinasi antara } \\
\text { wawancara tatap muka, tanpa tatap } \\
\text { muka (by phone), dan Computer Aided } \\
\text { Web Interviewing (CAWI) untuk isi } \\
\text { mandiri pada website melalui link Lime } \\
\text { Survey }\end{array}$ \\
\hline 7 & Instrumen & $\begin{array}{l}\text { (1) Buku Pedoman Pencacah dan } \\
\text { Pengawas } \\
\text { (2) Peta Blok Sensus/Subblok Sensus } \\
\text { (3) Kuesioner Listing Survei E- } \\
\text { commerce } \\
\text { (4) Daftar Sample Blok Sensus Terpilih } \\
\text { (5) Aplikasi Computer Assisted } \\
\text { Personal Interview (CAPI) } \\
\text { (6) Pelatihan Innas offline }\end{array}$ & $\begin{array}{l}\text { (1) Buku Pedoman Pencacah dan } \\
\text { Pengawas } \\
\text { (2) Kuesioner Sampel Survei E- } \\
\text { commerce } \\
\text { (3) Daftar Sample Perusahaan Terpilih } \\
\text { (4) Website CAWI melalui Link Lime } \\
\text { Survey E-commerce } \\
\text { (5) Pelatihan Innas online }\end{array}$ \\
\hline 8 & Anggaran & $\begin{array}{l}\text { (1) Pusat: Rp2.636.531.000,00 } \\
\text { (2) Daerah: Rp9.017.472.000,00 } \\
\text { (3) Total: Rp11.654.003.000,00 }\end{array}$ & $\begin{array}{l}\text { (1) Pusat: Rp859.388.000,00 } \\
\text { (2) Daerah: Rp3.255.094.000,00 } \\
\text { (3) Total: Rp4.114.482.000,00 }\end{array}$ \\
\hline
\end{tabular}

Sumber: Dirangkum dari dokumen-dokumen Survei E-commerce 2019 dan Survei E-commerce 2020 (BPS). 
Berdasarkan Tabel 1, Survei E-commerce yang dilakukan oleh BPS merupakan bagian dari RKP untuk Program Prioritas Nasional. Survei E-commerce 2019 merupakan bagian dari Program Prioritas Nasional Ketiga, yaitu "Peningkatan Nilai Tambah Pariwisata dan Jasa Produktif Lainnya" Khususnya Kegiatan Prioritas "Peningkatan Perdagangan Dalam dan Luar Negeri". Sementara pada tahun 2020, Survei E-commerce merupakan bagian dari Program Prioritas Nasional Pertama, yaitu "Memperkuat Ketahanan Ekonomi untuk Pertumbuhan yang Berkualitas dan Berkeadilan". Dari sisi cakupan, baik Survei E-commerce 2019 maupun Survei E-commerce 2020 sama-sama dilakukan di 34 provinsi dan 101 kabupaten/kota. Perbedaan terdapat dalam cakupan kategori usaha pada Klasifikasi Baku Lapangan Usaha Indonesia (KBLI), yang mana pada tahun 2019 mencakup seluruh kategori kecuali $\mathrm{O}$ dan T sedangkan pada tahun 2020 mencakup seluruh kategori kecuali O, T, dan U.

Perubahan pada metodologi menjadi perbedaan yang paling mencolok pada Survei $E$ commerce 2019 dan Survei E-commerce 2020, baik metode pemilihan sampel maupun metode pengumpulan data. Pada tahun 2019 dilakukan listing pada 3.504 blok sensus yang terpilih secara systematic sampling dan dilakukan pencacahan terhadap 18.516 usaha/perusahaan e-commerce. Sementara pada tahun 2020 dilakukan pencacahan lengkap (take all) terhadap 17.063 usaha/perusahaan e-commerce, terdiri atas 16.180 usaha/perusahaan hasil Listing Survei $E$ commerce 2019 dan 883 usaha/perusahaan e-commerce hasil big data crawling marketplace Shopee dari tim Polstat STIS yang dilengkapi dengan informasi nomor telepon/handphone. Nomor telepon digunakan untuk wawancara responden by phone sementara nomor handphone digunakan untuk menghubungi responden melalui sms blast. Baik nomor telopon maupun nomor handphone utamanya digunakan untuk verifikasi sehingga memudahkan petugas melakukan tracking alamat responden, selain tentunya digunakan untuk wawancara by phone dan sms blast.

Metode pengumpulan data yang pada tahun 2019 menggunakan wawancara tatap muka dan aplikasi CAPI berubah menjadi kombinasi antara wawancara tatap muka, wawancara tanpa tatap muka, dan isi survei mandiri yang tidak harus dilakukan tatap muka akibat pandemi Covid-19 yang menuntut minimalisasi kontak/tatap muka antara petugas dan responden. Wawancara tatap muka dilakukan secara door to door dengan tetap mematuhi protokol kesehatan di masa pandemi Covid19 sedangkan wawancara tanpa tatap muka dilakukan secara online by phone. Pengisian survei secara mandiri dilakukan oleh responden pada website CAWI melalui link Lime Survey yang dikirimkan kepada responden melalui sms blast beserta kode token yang unik untuk setiap responden sehingga menjamin bahwa hanya responden yang bersangkutan yang dapat mengisi survei. Sebelumnya, responden dikirimi sms blast berisi sosialisasi dengan sender ID BPS RI beserta tautan ke website BPS RI yang menampilkan running digital banner tentang pelaksanaan Survei $E$-commerce untuk meningkatkan kepercayaan responden.

Selain itu, pelatihan Instruktur Nasional (Innas) dan petugas yang pada Survei E-commerce 2019 dilakukan secara offline menjadi online melalui aplikasi Zoom pada Survei E-commerce 2020. Penyesuaian juga dilakukan terhadap mekanisme pembayaran pelatihan petugas dari fullboard meeting menjadi pembayaran biaya pulsa dalam rangka menunjang pelatihan petugas secara online. Penyesuaian terhadap mekanisme pembayaran lainnya dilakukan pada pembayaran honor pencacahan lapangan bagi petugas. Pada Survei E-commerce 2019 petugas pencacah memperoleh honor per responden dan paket pulsa dalam rangka menunjang penggunaan aplikasi CAPI sedangkan pada Survei E-commerce 2020 petugas pencacah memperoleh paket pulsa dalam rangka mendukung wawancara responden by phone dan honor per responden hanya jika petugas melakukan wawancara tatap muka. Perubahan tersebut dilakukan untuk menjaga keselamatan Innas dan petugas serta untuk menyesuaikan refocussing anggaran Survei E-commerce 2020 sebesar 64,69\% yaitu dari 11,694 Miliar Rupiah menjadi 4,114 Miliar Rupiah.

Dukungan Teknologi Informasi dan Komunikasi (TIK) untuk pencacahan lapangan Survei $E$ commerce 2019 dan 2020 pun berbeda. Pada tahun 2019 pencacahan responden di lapangan dilakukan menggunakan aplikasi Computer Assisted Personal Interview (CAPI) pada perangkat handphone oleh petugas pencacah sedangkan pada tahun 2020 pencacahan responden dilakukan menggunakan perangkat telepon/handphone untuk wawancara by phone, sms blast, serta mengirimkan link Lime Survey kepada responden yang bersedia mengisi survei secara mandiri melalui website CAWI. Perbedaan lainnya terdapat pada aksesibilitas web monitoring survei oleh 
BPS Pusat dan Daerah yang pada tahun 2019 hanya dapat mengkases informasi jumlah usaha/perusahaan yang sudah dan belum disurvei sampai level kabupaten/kota sedangkan pada tahun 2020 sudah dapat mengakses informasi nama usaha/perusahaan yang sudah dan belum disurvei sampai level kabupaten/kota.

Tabel 2 menyajikan secara ringkas kekuatan, kelemahan, peluang, dan tantangan (SWOT) Survei E-commerce 2020. Tabel ringkasan analisis SWOT tersebut kami sarikan dari perbandingan tata laksana antara Survei E-commerce 2019 dan Survei E-commerce 2020 pada Tabel 1. Secara fokus, Tabel 2 tersebut menyajikan kekuatan, kelemahan, peluang, dan tantangan (SWOT) Survei E-commerce 2020 yang dilaksanakan di masa pandemi Covid-19.

Di masa pandemi Covid-19, BPS diamanahi untuk tetap melaksanakan Survei E-commerce 2020 yang memiliki kekuatan sebagai bagian dari RKP untuk Program Prioritas Nasional Pertama, yaitu "Memperkuat Ketahanan Ekonomi untuk Pertumbuhan yang Berkualitas dan Berkeadilan". Di sisi lain, Survei E-commerce 2020 memiliki kekuatan dari aspek perubahan metodologi yang adaptif. Sebagaimana telah kami jelaskan pada paragraf terdahulu, Tabel 1 menyuguhkan perubahan metodologi pada Survei E-commerce 2020 yang relatif adaptif dibandingkan dengan Survei E-commerce tahun sebelumnya, antara lain perubahan pelatihan innas dari sebelumnya dilakukan secara tatap muka menjadi secara online, penggunaan hasil crawling Big Data dalam penyusunan kerangka sampel yang dilengkapi informasi nomor telepon/handphone, serta perubahan metode pengumpulan data dari wawancara tatap muka menjadi kombinasi antara wawancara tatap muka, wawancara tanpa tatap muka (by phone), dan isi survei mandiri melalui website CAWI yang memberikan pilihan kepada responden untuk meminimalisasi tatap muka antara petugas dan responden.

Selain mencerminkan aspek kekuatan, Survei E-commerce 2020 juga menyuguhkan 2 (dua) kelemahan, yaitu target response rate yang diturunkan dan pengisian kuesioner online melalui website CAWI berpotensi mengurangi tingkat kredibilitas hasil survei. Untuk mengantisipasi kelemahan pertama, Subdirektorat Statistik KTI BPS telah melakukan strategi pengumpulan data dengan wawancara tatap muka, disamping wawancara by phone dan isi survei mandiri tanpa tatap muka, untuk meningkatkan kepercayaan (trust) dari responden. Kondisi di lapangan, tidak sedikit responden menolak ketika akan dilakukan wawancara by phone atau menolak mengisi survei secara mandiri, namun ketika petugas mendatangi secara langsung ternyata responden bersedia untuk diwawancara secara tatap muka. Strategi dan upaya tersebut dilakukan untuk mengantisipasi tidak tercapainya target response rate Survei E-commerce 2020, dengan tetap menerapkan protokol kesehatan di masa pandemi Covid-19. Untuk mengantisipasi kelemahan kedua, Subdirektorat Statistik KTI BPS telah melakukan strategi penerapan rule validasi pada isian kuesioner online melalui website CAWI untuk menjaga kewajaran isian kuesioner, penggunaan token unik untuk menjamin bahwa hanya responden yang berhak saja yang dapat mengisi kuesioner online, serta menerapkan prosedur operasional standar pada proses micro editing isian hasil survei. Strategi dan upaya tersebut dilakukan untuk tetap menjaga kredibilitas hasil Survei $E$ commerce 2020.

Tabel 2. Ringkasan Analisis SWOT untuk Evaluasi Survei E-commerce 2020.

\begin{tabular}{lll}
\hline \multicolumn{1}{c}{ Kekuatan (Strengths) } & \multicolumn{1}{c}{ Kelemahan (Weakness) } \\
\hline $\begin{array}{l}\text { 1. Termasuk Program Prioritas Nasional } \\
\text { 2. Perubahan metodologi yang adaptif }\end{array}$ & $\begin{array}{l}\text { 1. } \\
\text { 2. Target response rate diturunkan } \\
\begin{array}{l}\text { Pengisian kuesioner online melalui website CAWI } \\
\text { berpotensi mengurangi tingkat kredibilitas hasil } \\
\text { survei }\end{array}\end{array}$ \\
\hline
\end{tabular}

Peluang (Opportunities)

Tantangan (Threaths)

1. Dukungan penggunaan Big Data Crawling 1. Dilakukan di masa pandemi Covid-19

Marketplace dari Tim Polstat STIS

2. Pengurangan budget anggaran

2. Innas dan petugas sudah berpengalaman dari pelaksanaan Survei E-commerce 2019

3. Pembatasan Sosial Berskala Besar (PSBB) yang diterapkan di masa pandemi Covid-19 mengubah pola belanja e-commerce

Sumber: Dokumen-dokumen terkait Survei E-Commerce 2020. 
Dari segi peluang, Survei E-commerce 2020 membuktikan penggunaan teknik Big Data untuk survei-survei di Subdirektorat Statistik KTI. Survei E-commerce 2020 yang dilakukan oleh Subdirektorat Statistik KTI sejatinya semakin mengukuhkan perluasan penggunaan Big Data sebagai dukungan di dalam kegiatan penyelenggaran statistik resmi yang dilakukan oleh BPS. Pada Survei E-commerce 2020, teknik Big Data digunakan sebagai dukungan (supporting) dalam penyediaan penambahan sampel usaha/perusahaan e-commerce ke dalam daftar sampel. Dengan

pertimbangan kebaruan data, Survei E-commerce 2020 hanya membatasi daftar usaha/perusahaan e-commerce yang diperoleh dari hasil crawling marketplace Shopee oleh Tim Polstat STIS. Adapun dari marketplace yang lain, daftar perusahaan hasil crawling belum terbarukan (up to date). Dukungan technical assistance Tim Polstat STIS dalam Big Data telah menjadi peluang tersendiri untuk tetap menyertakan dukungan Big Data dalam penyelenggaraan kegiatan statistik resmi. Dukungan ini menjadi nyata di saat-saat sulit seperti pandemi Covid-19 ini. Selain itu, pengalaman petugas dalam menggunakan dukungan Big Data sebagai dukungan survei pada Survei E-commerce 2019, telah mengukuhkan semangat Innas dan petugas untuk beradaptasi dengan pelaksanaan survei-survei yang dikombinasikan dengan teknik Big Data serta diharapkan dapat mendukung kelancaran kegiatan Survei E-commerce 2020.

Di sisi lain, Survei E-commerce 2020 mempunyai peluang mendapat berkah tersembunyi (blessing in disguise) dari kebijakan-kebijakan pemerintah yang diambil di masa pandemi, di antaranya kebijakan PSBB. Beberapa kajian/laporan menunjukkan bahwa terjadi perubahan transaksi e-commerce selama kebijakan PSBB. Publikasi BPS (2020) yang berjudul "Tinjauan Big Data terhadap Dampak Covid 19" dan "Analisis Big Data di Tengah Kebiasaan Baru" menyiratkan bahwa selama kebijakan PSBB pada bulan April-Juni 2020, terjadi kenaikan rata-rata produk terjual di marketplace selama tiga bulan terakhir sebesar $20 \%$ dibandingkan dengan penjualan pada bulan sebelumnya. Meskipun tentu saja terjadi pergeseran kategori yang mengalami kenaikan atau penurunan penjualan pada e-commerce. Pada Bulan April 2020, BPS mencatat volume transaksi 4,8 kali lebih banyak dibanding penjualan di bulan Januari 2020. Volume transaksi penjualan paling tinggi adalah kategori Makanan dan Minuman, sampai 10,7 kali penjualan di bulan Januari dan terendah adalah kategori Olahraga 1,7 kali bulan Januari 2020. Perubahan tersebut dapat digunakan untuk menangkap fenomena jumlah dan karakteristik $e-$ commerce yang tidak berlanjut, berubah, atau tetap bertahan selama pandemi Covid-19 2020 serta semakin memperkuat peran Survei E-commerce 2020 di masa pandemi Covid-19.

Selain peluang-peluang yang melegakan pada pelaksanaan Survei E-commerce 2020, Tabel 2 juga menyajikan tantangan nyata bagi Survei E-commerce 2020, yaitu: (1) Survei dilakukan di masa pandemi Covid-19; dan (2) Adanya pengurangan budget anggaran. Survei yang dilakukan di masa pandemi Covid-19 tentu mendatangkan tantangan nyata yang perlu diantisipasi oleh BPS dan organisasi survei di lapangan. Terdapat sekurang-kurangnya 2 (dua) permasalahan yang perlu dijawab terkait survei yang dilakukan di masa pandemi, yaitu bagaimana pelaksanaan survei di lapangan tetap menjamin keselamatan petugas dengan memperhatikan protokol kesehatan, di saat yang sama, target pencapaian response rate tercapai. Hal lain yang menjadi tantangan adalah pengurangan budget anggaran survei E-commerce 2020, seiring kebijakan refocusing anggaran pemerintah untuk penanggulangan/pemulihan dampak covid-19.

\section{KESIMPULAN}

Survei E-commerce 2020 telah menunjukkan beberapa kontribusi penting dalam mendukung Program Prioritas Nasional berdasarkan RKP 2020. Hal ini menjadi poin penting alasan Survei $E$ commerce 2020 harus tetap dilaksanakan di masa pandemi Covid-19. Pelaksanaan Survei Ecommerce 2020 di masa pandemi Covid-19 juga telah menuntut Subdirektorat Statistik KTI BPS untuk melakukan perubahan pada tata laksana survei dibandingkan dengan tata laksana Survei $E$ commerce 2019. Perubahan yang paling mencolok terdapat pada metodologi survei, baik metode pemilihan sampel maupun metode pengumpulan data. Dengan pengurangan anggaran hampir $70 \%$ dari perencanaan awal tahun akibat kebijakan refocussing anggaran nasional untuk pengendalian dampak pandemi Covid-19, Survei E-commerce 2020 tetap dilaksanakan.

Perubahan pada tata laksana survei memberikan peluang dan tantangan tersendiri bagi Subdirektorat Statistik KTI BPS untuk tetap menyajikan statistik resmi yang berkualitas sebagai 
dukungan terhadap program prioritas nasional. Berdasarkan hasil dan pembahasan di atas, Survei E-commerce 2020 merupakan salah satu survei BPS yang menggunakan dukungan Big Data dan dilakukan di masa pandemi Covid-19. Dengan memperhatikan sudut pandang internal dan eksternal, Survei E-commerce 2020 mempunyai peluang dan tantangan yang dapat dijadikan pelajaran untuk ke depannya apabila suatu saat terjadi force majeur, yang membuat BPS harus mempertimbangkan penyesuaian pada metodologi serta pada keseluruhan tata laksana kegiatan statistik.

\section{UCAPAN TERIMA KASIH}

Kami ucapkan terima kasih kepada Ibu Titi Kanti Lestari selaku Direktur Statistik Keuangan, Teknologi Informasi, dan Pariwisata BPS yang telah memberikan kepercayaan kepada tim penulis untuk membuat makalah kajian mengenai perbandingan Survei E-commerce 2019 dan Survei Ecommerce 2020. Kami juga menyampaikan ucapan terima kasih kepada pihak-pihak yang telah menyediakan data, termasuk kepada ketua gugus tugas penanggulangan Covid-19 nasional.

\section{DAFTAR PUSTAKA}

BPS (Badan Pusat Statistik). (2019). Buku Pedoman Pencacah dan Pengawas Survei E-commerce 2019. BPS. Jakarta.

BPS (Badan Pusat Statistik). (2020). Buku Pedoman Pencacah dan Pengawas Survei E-commerce 2019. BPS. Jakarta.

BPS (Badan Pusat Statistik). (2020). Tinjauan Big Data terhadap Dampak Covid-19. BPS. Jakarta

Gürel, E., \& Tat, M. (2017). SWOT analysis: a theoretical review. Journal of International Social Research, 10(51).

Hill, T., and Westbrook, R. (1997). SWOT Analysis: It's Time for a Product Recall. Long Range Plann, 30, 4652.

Kemenkeu (Kementerian Keuangan). (2020). Instruksi Presiden (Inpres) Nomor 4 Tahun 2020 tentang Refocussing Kegiatan, Realokasi Anggaran serta Pengadaan Barang dan Jasa Dalam Rangka Percepatan Penanganan Corona Virus Disease 2019 (COVID-19). Cited in https://www.kemenkeu.go.id/publikasi/pengumuman/instruksi-presiden-inpres-nomor-4-tahun-2020tentang-refocussing-kegiatan-realokasi-anggaran-serta-pengadaan-barang-dan-jasa-dalam-rangkapercepatan-penanganan-corona-virus-disease-2019-covid-19/. [6 Agustus 2020].

Laudon, K. C., \& Laudon, J. P. (1998). Management Information System, New Approaches to Organization and Technology. Prentice Hall. NJ.

Leigh, D. (2010). SWOT Analysis. Handbook of Improving Performance in the Workplace, 2, 115-140.

McLeod, R., \& Schell, G. P. (2007). Management information systems. Prentice Hall.

Organisation of Economic Co-operation and Development (OECD). (2011). OECD Guide to Measuring The Information Society 2011. 72-74.

Sevelius, J. M., Gutierrez-Mock, L., Zamudio-Haas, S., McCree, B., Ngo, A., Jackson, A., ... \& Stein, E. (2020). Research with Marginalized Communities: Challenges to Continuity During the COVID-19 Pandemic. AIDS and Behavior, 1.

Shelly, G. B., Cashman, T. J., \& Vermaat, M. E. (2007). Discovering Computers 2008, Brief. Course Technology Press.

Westbrook, R. (1997). SWOT Analysis: It's Time for a Product Recall. Long Range Plann, 30, 46-52.

Worldometer.

(2020).

Cited

in

https://www.worldometers.info/coronavirus/?utm_campaign=homeAdvegas1?\%22\#countries.

$[4$

Agustus 2020]. 